\title{
Attitudes of management students towards workplace ethics: A comparative study between South Africa and Cyprus
}

\author{
Adèle Thomas, Maria Krambia- \\ Kapardis \& Anastasios Zopiatis
}

\begin{abstract}
In order to understand attitudes towards workrelated ethics and the teaching of business ethics in management programmes at universities, a survey was conducted with management students at two universities, one in the Republic of Cyprus (hereafter referred to as Cyprus) and the other in the Republic of South Africa (hereafter referred to as South Africa). An attempt was also made to investigate whether such differences, if any, were linked to differences in national culture. The findings indicate that no significant differences between the two samples exist on four of the five dimensions of national culture (Hofstede, 1994) and, accordingly, differences in attitudes towards workplace ethical issues cannot be said to be linked to this variable. Significant differences were found between the two samples on certain questionnaire items that related to workplace practices with the Cypriot sample, more so than the South African sample, appearing to be willing to engage in certain workplace practices that would be deemed unethical in society. It is recommended that ethics education be integral to a business curriculum and that teaching methodologies explore ways in which to develop moral reasoning in students.
\end{abstract}

Key words: South Africa, Cyprus, ethics, management, culture, quantitative survey

\section{Introduction}

The link between ethical organisational practices and competitive advantage is increasingly becoming apparent (Amalric \& Hauser, 2005; Aqueveque, 2005; Gildia, 1995; Holland, 2002; Hosmir, 1994; Verschoor, 1998). Companies that exhibit ethical behaviour in terms of the triple bottom line - socially, economically and environmentally - are less likely to negatively surprise shareholders and are less likely to suffer the negative publicity and litigation that accompanies the exposure of poor governance practices (Holland, 2002). Stahli (2005, p. 122) highlights the challenge to business managers of simultaneously balancing the achievement of economic and financial

Adèle Thomas is a Professor in the Department of Business Management at the University of Johannesburg where she coordinates the research programme of the Masters in Business Management

Maria Krambia-Kapardis is an Associate Professor in Accounting at the Cyprus University of Technology, Limassol, Cyprus.

Anastasios Zopiatis is a Lecturer in the Department of Hotel Tourism Management at the Cyprus University of Technology, Limassol, Cyprus. goals with that of effecting sound corporate governance and notes that "to find and hold the correct balance belongs ... to the most demanding and honourable tasks of executives".

Increased globalisation and accompanying competition has increased corruption (Johnstone \& Brown, 2004; Theobold, 2002), recognised to be one of the most pressing problems of business (Everett, Neu \& Rahaman, 2006; Pacini, Swingen \& Rogers, 2002; Ryan, 2000; Weber \& Getz, 2004). Fassin (2005, p. 266) notes how, in spite of the exposure of corporate scandals, unethical behaviour towards stakeholders is increasing at all organisational levels. Merritt (2002) notes that polls indicate that business executives are publicly viewed as being less ethical than politicians.

In order to develop and sustain ethical corporate cultures, current employees not only have to be held accountable for ethical practices, but companies need to recruit ethical employees. Arguably business schools and universities offering management degrees, the producers of business graduates, are challenged to consider whether or not they can impact the ethical behaviour of students that would assist in developing morally sensitive managers.

Studies indicate that significant differences in business ethics exist across countries (Sims, 2006; Sims \& Gegez, 2004) and that cultural factors can impact ethical beliefs and attitudes (Walker \& Jeurissen, 2003).

The present study explores whether differences exist in the attitudes to work-related ethical practices between business management students in South Africa and the Republic of Cyprus. It also explores whether there is a significant difference between Cypriot and South African business students on Hofstede's (1994) dimensions of national culture and, if so, whether there is a link between such differences and attitudes towards workplace ethics. Such cross-cultural ethics research, Whipple and Swords (1992) note, can promote the development of educational and training programmes for aspiring business managers.

\section{National culture}

Hofstede $(1991 ; 1994 ; 1997 ; 2001)$ is perhaps the most well known researcher and the most often cited one in the field of national culture. He was the first to use survey research and quantitatively analyse the influence 
of national culture in the workplace, initially across 50 countries, expanding to 74 countries and regions (Hofstede, 2001). More recently, House, Hanges, Javidan, Dorfman and Gupta (2004) produced the GLOBE study of national culture in 62 societies that includes similar, different and expanded categories to those devised by Hofstede (2001).

Hofstede (2001) describes the five dimensions of national culture as follows:

- Individualism - Collectivism (IDV) is the degree of individual or group orientation in a society. In an individual environment the rights of individuals supersede those of the group. In a collective environment, strong loyalties to extended families or communities prevail.

- Power Distance (PDI) is the level of preference for equality or inequality within groups, reflecting the extent to which organisational members accept that power is unequally distributed. In high power distance cultures centralised, top-down control prevails. In such cultures, people prefer little consultation between superiors and subordinates. In low power distance cultures greater equality and empowerment is evident and individuals prefer greater consultation by leaders.

- Uncertainty Avoidance (UAI) is a measure of the level of comfort people experience with ambiguity and risk. In high uncertainty avoidance cultures people are willing to take extra risks. In low uncertainty avoidance cultures, predictability is preferred.

- Masculinity-femininity (MAS) describes a task versus relationship orientation. Masculine societies emphasise money and things while feminine societies are concerned about relationships, nurturing and quality of life.

- Long- versus short-term orientation (LTO) describes the extent to which a group invests for the future. In a long-term orientation society the focus is on perseverance and patience. In a short-term orientation society, the focus is on the immediate and there is an expectation of quick results (Hofstede \& Bond, 1988).

Hofstede (1994) reports that South Africa is considered to reflect a moderate score on the following: power distance (VSM score of 49), uncertainty avoidance (VSM score of 49), individualism (VSM score 65) and masculinity (VSM score of 63). A study conducted by Thomas and Bendixen (2000) found a South African sample of middle managers to evidence scores that differed to those found by Hofstede (1994) on all dimensions except that of uncertainty avoidance. Utilising Hofstede's (1994) instrument, it is suggested, is not without its problems in a heterogeneous society such as South Africa where a multitude of language, ethnic, cultural and religious groups exist.
Okazaki (2007) reports on the dearth of cross cultural research in new EU-entry countries such as Cyprus. Indeed, an extensive literature search, as part of the present study, could not locate any data that employed the Hofstede (1994) VSM instrument for studying national culture in Cyprus. Droussiotis (2003), however, notes that Cypriot employees rate high on accepting unequal power between managers and employees, possibly equated to high power distance (Hofstede, 1994) and being risk averse, possibly equated to high uncertainty avoidance (Hofstede, 1994).

\section{National culture and ethics}

While the major criticisms levelled at Hofstede (2001) include his generalisations about national culture based upon an analysis of sub-national populations and his inferring of national culture from averaging situationally-specific opinions of culture (McSweeney, 2002), many studies have utilised Hofstede's (1994) VSM instrument to study inter-country comparative ethical attitudes, decision-making and business practices (Armstrong, 1996; McKinnon, 2002; Nyaw \& Ng, 1994; Patel, Harrison \& Sims, 2006; Sims \& Gegez, 2004; Tsui, 1996; Tsui \& Windsor, 2001). Sondergaard (1994) reports that over 60 published replications using the VSM instrument largely confirm Hofstede's (1994) findings.

Appelbaum (2006, p. 67) defines ethics as "a set of moral values that govern a person's behaviour or how an activity is conducted ... the moral standards of society". Earlier Rokeach (1968) noted values to be the enduring beliefs that certain end states are preferable to opposing end states. Sullivan (2005, p. 29) believes that ethics is "how we choose, in virtually every decision we make, to treat the people we work with and for, and the world around us".

The latest report of Transparency International (2007), in a review of 180 countries, ranks Cyprus in $39^{\text {th }}$ position and South Africa in $43^{\text {rd }}$ position with corruption perception indices of 5.3 and 5.1 respectively, where a score of ten denotes perceptions of a highly clean society and a score of zero, a highly corrupt one. Thus, the two countries rank relatively evenly in how they are perceived in terms of corruption.

The literature appears divided on the link between national culture and ethics. Abratt, Nel and Higgs (1992), Grünbaum (1997), Maynard (2000) and Whipple and Swords (1992) report no significant link between national culture and ethics. Mixed results are noted by Sims (2006) and Sims and Gegez (2004). A positive correlation between national culture and ethics is suggested by Alderson and Kakabadse (1994), Armstrong and Sweeney (1994), Jackson and Artola (1997), Kennedy and Lawson (1996), McDonald and Kan (1997), Moore and Randolf (1996), Singhapakdi, Rallapalli, Rao and Vitell (1995) and Walker and Jeurissen (2003). 
Supporting the link between national culture and ethics, Husted (1999) reports a relationship to exist between levels of societal corruption and power distance, uncertainty avoidance and masculinity, while Getz and Volkema (2001) found a link between levels of corruption and power distance and uncertainty avoidance.

\section{Ethics and business students}

Born (2003), Pillsbury (2004), Premeaux (2005) and Sterngold (2004) report the rise in academic misconduct and plagiarism internationally. Cascado, Miller and Vallen (1994) and Yeung, Wong and Chan (2002) note the decline in moral standards among university students. With specific reference to business students, Cowton and Cummins (2003) note their lack of sensitivity to business ethics and Giacalone (2004) believes that business students lack an aspirational vision that transcends the profit motive.

Bernardi, Giuliano, Komatsu, Potter and Yamamoto (2004) suggest that students may replicate academic dishonesty, such as cheating behaviour, in other environments. Felton and Sims (2005) remark how, during the past few years, former business students have been at the centre of corporate scandals. Collins (2000), Granitz and Loewy (2007) and Salter, Gufffey and McMillan (2001) suggest that unethical behaviour of students may later translate into unethical behaviour in business.

Referring to Hofstede's (2001) work, Walker and Jeurissen (2003) propose that, from the evidence of national culture differences among managers, it can be inferred that there will be national cultural differences among management students. Axinn, Blair, Heorhiadi and Thach (2005) and Christies, Kwon, Stoeberl and Bauhar (2003) note the role that cultural factors play in shaping ethical beliefs and attitudes of students. Corroborating Hofstede's (1991) research, Nyaw and $\mathrm{Ng}$ (1994) report differences in ethical attitudes among business students from Canada, Japan, Hong Kong and Taiwan. Zhang, Straub and Kusyk (2007) report differences between Canadian and French students' work and life values. Ahmed, Chung and Eichenseher (2003) note differences in perceptions of ethicality between business students from China, Egypt, Finland, Korea, Russia and the USA and Grünbaum (1997) notes differences in attitudes towards business ethics between Finnish and American business students.

After an extensive literature review of student attitudes towards and perceptions of ethics, only two relatively dated studies on attitudes towards business ethics of South African students were located (Haswell, Judd \& Wearing, 1999; Moore \& Radloff, 1996). Zopiatis and
Krambia-Kapardis (2008) note that prior to their study, no research into the ethical judgments of students in tertiary education had been conducted in the Republic of Cyprus. Thus the area of study reported in this paper is new both in its exploration of student attitudes towards ethics in these countries and the possible link to national culture.

McWilliams and Nahavandi (2006) report that up until the $20^{\text {th }}$ Century one of the main objectives of college education was to develop ethical and moral members of society, beginning with the development of the moral character of students. This philosophy was exemplified by Harvard University requiring students to read for a capstone course in moral philosophy taught by the President of the University (Bok, 1990). In recent years, in response to corporate scandals, a trend has grown for the burden of addressing business ethics in the student curriculum to be borne largely by business schools (McWilliams \& Nahavandi, 2006). In fact, Curren and Harich (1996) report that the Association to Advance Collegiate Schools of Business (AACSB) has promoted the teaching of ethics in business school programmes since the early 1980's, with Pulley (2005) noting that the majority of US business schools require one or more courses in ethics to be taken by students.

It is against this background that the present study aims:

- to ascertain whether differences exist in attitudes of business students in South Africa and in Cyprus with regard to ethical work-related practices;

- to ascertain whether business students in South Africa and Cyprus evidence any differences on the Hofstede (1994) dimensions of national culture;

- to link differences in national culture, if any, to attitudes to ethical work-related practices; and

- to ascertain whether business students regard the teaching of business ethics to students as important.

Accordingly, the following propositions are posited:

- Proposition No. 1: Business students in South Africa and Cyprus differ in their attitudes to ethical workrelated practices.

- Proposition No. 2: Business students in South Africa and Cyprus differ on Hofstede's (1994) dimensions of national culture.

- Proposition No. 3: Attitudes to ethical work-related practices are linked to differences in national culture, and

- Proposition No. 4: Business students in South Africa and Cyprus differ in the importance they place on the teaching of business ethics to students. 


\section{Research design}

\section{Research approach}

This quantitative exploratory study utilised closed-ended questionnaires, including the Hofstede (1994) VSM instrument, to collect data from 67 Master of Commerce (MCom) students at the University of Johannesburg in South Africa and 43 Master of Business Administration (MBA) students at Intercollege in the Republic of Cyprus.

\section{Participants}

The population of the study comprised all students studying a business degree at a master's level at any tertiary institution in both countries. Turkish-occupied North Cyprus was not included in the present study. A convenience sample of two institutions, the University of Johannesburg in South Africa and Intercollege in Cyprus, was utilised. The study aimed to survey the attitudes of all students registered for an MCom or MBA programme, irrespective of the year of study, within the two to three year programmes offered at each institution. The MCom and MBA programmes are comparable in curriculum content. Students had to be nationals of the two countries under review.

In South Africa, the total number of students registered was 95 from which four foreign students were excluded. From this total of 91 students, 67 useable responses were obtained. In Cyprus, from the 70 registered students, 22 foreign students were excluded from the study. From the balance of 48 students, 43 useable responses were obtained.

Foreign students were not included in the present study as one component of the study sought to compare dimensions of national culture between South African and Cypriot students. The presence of foreign students in the samples would, thus, contaminate it.

\section{Method of data gathering}

A three-part questionnaire comprising closed questions was utilised in the present study.

The first part of the questionnaire was designed to gather demographic data from the respondents. Part Two utilised the Values Survey Module VSM94 (Hofstede, 1994) to ascertain national culture based on the dimensions of power distance, individualism, masculinity, uncertainty avoidance and long-term orientation. Part Three posed a number of work-related ethical dilemmas to assess student attitude towards ethical/ unethical behaviour where respondents could rate their answers on a four-point Likert scale ranging from 'always' to 'never'.

Part Three of the questionnaire was pretested on samples of ten respondents in each country. In only one question was modification required to ensure that the question was clear to respondents in both countries.

Brimble and Stevenson-Clarke (2005), Marsden, Carroll and Neill (2005) and Sheard, Markham and Dick (2003) note that the majority of studies investigating ethics of students rely on survey responses that indicate attitudes and perceptions but which do not provide in-depth insights into motivations for such responses.

\section{Procedure}

The questionnaires were personally administered by the researchers to all classes of MCom and MBA students at the University of Johannesburg, South Africa and at Intercollege, Nicosia, Cyprus respectively, during the period March - May 2007. The purpose of the study was explained to students, anonymity was guaranteed and students were informed that participation in the study was voluntary.

\section{Analysis of data}

Simple frequency counts were used to analyse the demographic data obtained from Part One of the questionnaire. Data from Part Two of the questionnaire, incorporating the Values Survey Module VSM-94 (Hofstede, 1994), were analysed according to instructions that accompany the instrument. Data from Part Three of the questionnaire were analysed using the Statistical Package for Social Sciences (SPSS, version 15) utilising descriptive and inferential statistics, viz. crosstabulations with Chi Square (Pearson) and independent sample $t$-tests.

\section{Results}

\section{Demographic profile}

The demographic profile of the respondents obtained from Part One of the questionnaire is summarised in Table 1 below. 
TABLE 1:

DEMOGRAPHIC PROFILE OF RESPONDENTS

\begin{tabular}{|c|c|c|c|c|}
\hline & \multicolumn{2}{|c|}{ Cypriot } & \multicolumn{2}{|c|}{ South African } \\
\hline & Frequency & Percent & Frequency & Percent \\
\hline \multicolumn{5}{|l|}{ Gender: } \\
\hline Male & 22 & 51.2 & 45 & 67.2 \\
\hline Female & 21 & 48.8 & 22 & 32.8 \\
\hline \multicolumn{5}{|l|}{ Age: } \\
\hline $20-25$ & 20 & 46.5 & 7 & 10.5 \\
\hline $26-30$ & 12 & 27.9 & 18 & 27.0 \\
\hline $31-40$ & 9 & 20.9 & 33 & 49.3 \\
\hline $41-50$ & 2 & 4.7 & 8 & 12,0 \\
\hline No response & - & - & 1 & 1.9 \\
\hline \multicolumn{5}{|l|}{ Education: } \\
\hline Bachelor & 25 & 58.1 & 55 & 82.1 \\
\hline Master & 17 & 39.5 & 10 & 15.0 \\
\hline Doctorate & 1 & 2.3 & 1 & 1.5 \\
\hline No response & - & - & 1 & 1.5 \\
\hline \multicolumn{5}{|l|}{ Religion: } \\
\hline No & 1 & 2.3 & 7 & 10.5 \\
\hline Yes & 39 & 90.7 & 58 & 86.6 \\
\hline No response & 3 & 7.0 & 2 & 3.0 \\
\hline \multicolumn{5}{|l|}{ Industry/Sector: } \\
\hline Education & 3 & 7.0 & 6 & 9.0 \\
\hline Mining and quarrying & - & - & 3 & 4.5 \\
\hline Electricity, Gas, Water & - & - & 2 & 3.0 \\
\hline Construction & 3 & 7.0 & 2 & 3.0 \\
\hline $\begin{array}{l}\text { Retail motor trade \& repair } \\
\text { services }\end{array}$ & 1 & 2.3 & 4 & 6.0 \\
\hline $\begin{array}{l}\text { Wholesale trade, commercial } \\
\text { agents \& allied services }\end{array}$ & 3 & 7.0 & - & - \\
\hline $\begin{array}{l}\text { Catering, accommodation \& } \\
\text { related trade }\end{array}$ & 1 & 2.3 & 1 & 1.5 \\
\hline Transport and storage & - & - & 2 & 3.0 \\
\hline Communication & 7 & 16.3 & 2 & 3.0 \\
\hline Business \& Financial services & 11 & 25.6 & 21 & 31.3 \\
\hline Community \& Social services & - & - & 2 & 3.0 \\
\hline Consulting & - & - & 6 & 9.0 \\
\hline Other & 14 & 32.6 & 16 & 23.9 \\
\hline \multicolumn{5}{|l|}{ Nature of the organisation: } \\
\hline Public listed & 13 & 30.2 & 28 & 41.8 \\
\hline Private not listed & 16 & 37.2 & 15 & 22.4 \\
\hline Government & 3 & 7.0 & 10 & 14.9 \\
\hline Semi-government & 6 & 14.0 & 7 & 10.4 \\
\hline University & 2 & 4.7 & 3 & 4.5 \\
\hline Family Business & 1 & 2.3 & 4 & 6.0 \\
\hline No response & 2 & 4.7 & - & - \\
\hline \multicolumn{5}{|l|}{ Management Category: } \\
\hline Top management & 2 & 4.7 & 6 & 9.0 \\
\hline Middle Management & 6 & 14.0 & 26 & 39.0 \\
\hline Junior Management & 7 & 16.3 & 10 & 15.0 \\
\hline Supervisory & 6 & 14.0 & 1 & 1.5 \\
\hline Specialist/Professional & 7 & 16.3 & 14 & 21.0 \\
\hline Not applicable in job & 12 & 28.0 & 9 & 13.5 \\
\hline No response & 4 & 9.3 & 1 & 1.5 \\
\hline
\end{tabular}

In summary, the Cypriot sample was younger and more educated at post-graduate level than the South African sample, and included a larger percentage of female subjects. The majority of both samples reported belonging to some religious group/faith and to being employed in business and financial services (the largest single work category). The majority of both samples was employed in public listed or private non-listed companies. The South African sample members held a greater number of managerial positions than did the Cypriot sample.

\section{Dimensions of national culture}

The similarities in age, gender profile, education level and occupation complied with Hofstede's (1994) requirements for international sample comparisons. Tables 2 and 3 compare the South African and Cypriot respondents on the basis of Hofstede's (1994) five dimensions of national culture (Part Two of the questionnaire).

TABLE 2:

Comparison of SOUTH AFrican AND CyPRIOT RESPONDENTS ON HOFSTEDE'S (1994) DIMENSIONS

\begin{tabular}{lccccc}
\hline Country & PDI & IDV & MAS & UAI & LTO \\
\hline South Africa & 30 & 95 & 26 & 78 & 34 \\
\hline Cyprus & 12 & 84 & 21 & 81 & 23 \\
\hline
\end{tabular}

PDI $=$ Power Distance; IDV = Individualism-Collectivism; MAS=MasculinityFemininity; UAI = Uncertainty Avoidance; $\mathrm{LTO}=$ Long-Term Orientation

TABLE 3:

NATIONAL DIFFERENCES - SOUTH AFRICAN vs CyPRIOT RESPONDENTS

\begin{tabular}{llcccccc}
\hline Dimension & Group & $\mathrm{N}$ & Mean & $\begin{array}{c}\text { Std. } \\
\text { Deviation }\end{array}$ & $\mathrm{t}$ & $\mathrm{DF}$ & $\begin{array}{c}\text { Sig. } \\
\text { (2-tailed) }\end{array}$ \\
\hline Individual- & Cypriot & 43 & 1.68 & .537 & .775 & 108 & .440 \\
ism & South African & 67 & 1.60 & .519 & & & \\
\hline Uncertainty & Cypriot & 43 & 2.70 & .420 & .632 & 108 & .529 \\
Avoidance & South African & 67 & 2.64 & .566 & & & \\
\hline Masculinity & Cypriot & 43 & 2.41 & .425 & 1.243 & 108 & .217 \\
& South African & 67 & 2.30 & .485 & & & \\
\hline Power & Cypriot & 43 & 2.25 & .454 & .978 & 108 & .330 \\
Distance & South African & 67 & 2.15 & .533 & & & \\
\hline Long-Term & Cypriots & 43 & 2.18 & .599 & 2.250 & 108 & $.026 *$ \\
Orientation & South African & 67 & 1.93 & .528 & & & \\
\hline
\end{tabular}

* Significance level $=p<.05$

Note: equal variances assumed

From Tables 2 and 3 above, it can be seen that, while the Cypriot and South African samples differed on four of the five dimensions of national culture, a statistical difference between the samples was evident in the longterm orientation (LTO) dimension only $p=.026$. South African respondents attributed more importance to this dimension particularly with regard to the element of persistence $(t=3.003 ; d f=108 ; p=.003)$. 


\section{Attitudes towards ethical issues}

The findings of attitude towards ethical issues are represented below (Part Three of the questionnaire) divided into the following groupings:

- personal values;

- perceptions of organisational values and practices;

- attitude to work practices; and

- attitude to the teaching of business ethics.

In the analysis of the questions the categories 'always' and 'often' were grouped together as were the categories 'seldom' and 'never' in order to provide a more meaningful analysis of the data.

\section{Personal values}

Comparing the personal values articulated by the Cypriot and South African respondents as indicated in Table 4, it can be seen that they differed significantly on three of the seven statements related to this issue. Significantly more Cypriot than South African respondents noted that they would:

- Falsify tax returns to save on $\operatorname{tax}\left[x^{2}=6.52 ; p=.011\right]$;

- Alter their ethics due to peer pressure $\left[x^{2}=9.50\right.$; $p=.002]$; and

- Intentionally pay a bill late yet still attempt to secure an 'early payment' discount $\left[x^{2}=8.43 ; p=.004\right]$.

While on these three items the Cypriot sample appeared more willing than the South African sample to engage in behaviours that could be deemed to be ethically problematic in society, the scores indicated that the majority of respondents in both samples reported that they would not engage in such behaviours.

TABLE 4:

Personal VALUeS ORIENTATION

\begin{tabular}{lcccc}
\hline Value & $\begin{array}{c}\text { SA sample } \\
(\%)\end{array}$ & $\begin{array}{c}\text { Cypriot } \\
\text { sample (\%) }\end{array}$ & $\begin{array}{c}\text { Chi- } \\
\text { Square }\end{array}$ & P \\
\hline $\begin{array}{l}\text { I know what constitutes ethical } \\
\text { behaviour in my organization }\end{array}$ & 89.6 & 78.0 & 2.337 & .102 \\
\hline $\begin{array}{l}\text { Ethical actions are important } \\
\text { to me }\end{array}$ & 95.5 & 95.1 & .006 & .937 \\
\hline $\begin{array}{l}\text { I would falsify my tax returns to } \\
\text { save on tax }\end{array}$ & 13.6 & 35.1 & 6.524 & $.011^{*}$ \\
\hline $\begin{array}{l}\text { Peer pressure causes me to alter } \\
\text { my ethics }\end{array}$ & 9.0 & 32.5 & 9.508 & $.002^{\star *}$ \\
\hline $\begin{array}{l}\text { I would intentionally pay a bill } \\
\text { late yet still try to get an 'early } \\
\text { payment' discount }\end{array}$ & 10.4 & 33.3 & 8.434 & $.004^{\star *}$ \\
\hline $\begin{array}{l}\text { I admire someone's wealth } \\
\text { regardless of how he/she } \\
\text { obtained it }\end{array}$ & 13.6 & 28.2 & 3.374 & .066 \\
\hline $\begin{array}{l}\text { I would be prepared to sacrifice } \\
\text { money to act ethically }\end{array}$ & 77.6 & 61.5 & 3.139 & .076 \\
\hline
\end{tabular}

* Significance level $=p<.05$

** Significance level $=p<.01$
The majority of respondents in both samples indicated that they knew what constitutes ethical behaviour, that they personally regarded ethics as important and that they would be prepared to sacrifice money to act ethically. No statistically significant differences were found between the two samples in terms of these items. However, it is interesting to note that the previous finding indicated that respondents were nevertheless willing to engage in unethical behaviour.

\section{Perceptions of organisational values and practices}

Regarding the respondents' perceptions of their organisational values, as noted in Table 5, there were statistically significant differences between the Cypriot and South African respondents in half of the items dealing with this issue (three out of six statements).

TABLE 5:

PERCEPTIONS OF ORGANISATIONAL VALUES AND PRACTICES

\begin{tabular}{lcccc}
\hline Value & $\begin{array}{c}\text { SA } \\
\text { sample } \\
(\%)\end{array}$ & $\begin{array}{c}\text { Cypriot } \\
\text { sample } \\
(\%)\end{array}$ & $\begin{array}{c}\text { Chi- } \\
\text { Square }\end{array}$ & $P$ \\
\hline $\begin{array}{l}\text { I am satisfied with the ethics that my } \\
\text { organisation upholds }\end{array}$ & 85.1 & 69.2 & 3.762 & .052 \\
\hline $\begin{array}{l}\text { Moral standards in my organisation } \\
\text { are fully understood }\end{array}$ & 81.8 & 67.5 & 2.833 & .092 \\
\hline $\begin{array}{l}\text { My employer makes me compromise } \\
\text { my ethical standards }\end{array}$ & 7.5 & 35.9 & 13.548 & $.000^{*}$ \\
\hline $\begin{array}{l}\text { My organisation gives out dishonest } \\
\text { statements about product quality, } \\
\text { comparative prices etc }\end{array}$ & 16.4 & 12.5 & .302 & .582 \\
\hline $\begin{array}{l}\text { My organisation uses bribes to obtain } \\
\text { business }\end{array}$ & 3.1 & 20.5 & 8.527 & $.004^{*}$ \\
\hline $\begin{array}{l}\text { My organisation bribes to gain } \\
\text { business in a foreign country }\end{array}$ & 1.5 & 22.5 & 12.837 & $.000^{*}$ \\
\hline
\end{tabular}

* Significance level $=p<.01$

While scores from both samples indicated a greater tendency towards perceptions of ethical as opposed to unethical organisational values and practices, members of the Cypriot sample, significantly more than members of the South African sample, stated that:

- Their employers caused them to compromise their ethical standards $\left[x^{2}=13.54 ; p=.000\right]$;

- Their companies used bribes to obtain business $\left[x^{2}=8.52 ; p=.004\right]$; and

- Their companies offered bribes to gain business in foreign countries $\left[x^{2}=12.83 ; p=.000\right]$.

Of note, in the light of the above findings, is that 67,5 percent of the Cypriot sample indicated that moral standards in their companies were not understood, although 69,2 percent expressed satisfaction with the ethics of their companies. In contrast, while not statistically different, the scores of the South African sample on these two items were 81,8 percent and 85,1 percent respectively. 


\section{Attitude to work practices}

With regard to attitude to work practices, significant differences between the two groups of respondents were found on nine of the 15 dimensions as noted in Table 6.

TABLE 6:

ETHICS AND WORK PRACTICES

\begin{tabular}{|c|c|c|c|c|}
\hline Value & $\begin{array}{c}\text { SA } \\
\text { sample } \\
(\%)\end{array}$ & $\begin{array}{l}\text { Cypriot } \\
\text { sample } \\
(\%)\end{array}$ & $\begin{array}{l}\text { Chi- } \\
\text { Square }\end{array}$ & $P$ \\
\hline $\begin{array}{l}\text { The ethics that I practice at work are } \\
\text { the same as the ones I practice at home }\end{array}$ & 90.9 & 65.9 & 10.446 & $.001^{* *}$ \\
\hline $\begin{array}{l}\text { Competition for business makes me } \\
\text { alter my ethics }\end{array}$ & 6.0 & 31.7 & 12.703 & $.000^{* *}$ \\
\hline $\begin{array}{l}\text { I turn in honest expense accounts at } \\
\text { work }\end{array}$ & 86.6 & 95.0 & 1.931 & .165 \\
\hline $\begin{array}{l}\text { I would be willing to use inside } \\
\text { information even if I could gain from it }\end{array}$ & 25.4 & 43.9 & 3.987 & $.046^{*}$ \\
\hline $\begin{array}{l}\text { I would harm others to achieve } \\
\text { advancement }\end{array}$ & 3.0 & 14.6 & 5.032 & $.025^{*}$ \\
\hline $\begin{array}{l}\text { I would expect my staff to chase profits } \\
\text { if it means going against their own } \\
\text { values }\end{array}$ & 6.0 & 15.0 & 2.411 & .121 \\
\hline $\begin{array}{l}\text { As a manager, I would accept } \\
\text { responsibility for errors in the } \\
\text { department }\end{array}$ & 86.6 & 82.1 & .392 & .531 \\
\hline $\begin{array}{l}\text { I would be willing to 'head-hunt' } \\
\text { someone who would give me trade } \\
\text { secrets of my competitor }\end{array}$ & 20.9 & 20.0 & .012 & .912 \\
\hline $\begin{array}{l}\text { If we held excess stock I would } \\
\text { try to return it on the pretence of } \\
\text { defective goods or goods not made to } \\
\text { specification }\end{array}$ & 4.5 & 25.6 & 10.261 & $.001^{* *}$ \\
\hline $\begin{array}{l}\text { I would engage in price-fixing with a } \\
\text { competitor to benefit my organisation }\end{array}$ & 10.4 & 47.5 & 18.693 & $.000^{* *}$ \\
\hline $\begin{array}{l}\text { I would be willing to use tactics } \\
\text { that might injure, hurt or destroy } \\
\text { competition }\end{array}$ & 10.4 & 29.3 & 6.214 & $.013^{*}$ \\
\hline $\begin{array}{l}\text { I would be willing to cut corners in } \\
\text { quality or service to maximise profits }\end{array}$ & 6.0 & 20.5 & 5.193 & $.023^{*}$ \\
\hline $\begin{array}{l}\text { At the end of the day I am satisfied } \\
\text { that, at work, I behaved according to } \\
\text { my values }\end{array}$ & 92.5 & 80.0 & 3.689 & .055 \\
\hline $\begin{array}{l}\text { Ethical decision-making is possible at } \\
\text { work }\end{array}$ & 91.0 & 82.5 & 1.713 & .191 \\
\hline $\begin{array}{l}\text { People who 'blow the whistle' in } \\
\text { companies are acting morally }\end{array}$ & 89.6 & 51.4 & 19.050 & $.000^{* *}$ \\
\hline
\end{tabular}

* Significance level $=\mathrm{p}<.05$

** Significance level $=\mathrm{p}<.01$

With regard to seven of the nine items, significantly more members of the Cypriot sample than the South African sample reported that they would:

- alter their ethics for the sake of competition for business $\left[x^{2}=12.70 ; p=.000\right]$;

- be willing to use insider information for gain $\left[x^{2}=3.98\right.$; $p=.046]$;

- be willing to harm others to achieve advancement $\left[x^{2}=5.03 ; p=.025\right]$;

- endeavour to return excess stock for dishonest reasons $\left[x^{2}=10.26 ; p=.001\right]$;
- engage in price-fixing for organisational benefit $\left[x^{2}=18.69 ; p=.000\right]$;

- be willing to use unfair tactics against the competition $\left[x^{2}=6.21 ; p=.013\right] ;$ and

- be willing to cut corners in quality or service to maximise profits $\left[x^{2}=5.19 ; p=.023\right]$.

Significantly more members of the South African sample than the Cypriot sample reported that they:

- Tended to practice the same ethics at home and at work $\left[x^{2}=10.44 ; p=.001\right]$; and

- Regarded whistleblowing as moral $\left[x^{2}=19.05\right.$; $p=.000]$.

While statistical significant differences exist between the two samples on the nine items noted above, the scores for both samples reflect a general tendency towards ethical behaviour on four of the first seven items noted above (altering ethics for the sake of competition, harming others to achieve advancement, using tactics to destroy competition and cutting corners to maximise profits). What is of more concern is that almost 44,0 percent of the Cypriot sample and approximately 25,0 percent of the South African sample reported that they would be willing to use insider information to achieve advancement. Furthermore, with regard to the Cypriot sample, 25,6 percent reported being willing to return stock for dishonest reasons, 47,5 percent would be willing to engage in price-fixing and 51,4 percent did not regard whistleblowing as morally correct. Only 65,9 percent of the Cypriot sample believed that the ethics that they practice at work are congruent with the ones they practice at home although, at the end of the day, they reported being satisfied that at work they behave according to their values (80,0 percent).

\section{Teaching business ethics to students}

No statistically significant difference was found with regard to the teaching of business ethics to students to develop future moral leaders, although both samples regarded the teaching of business ethics as being important as indicated in Table 7.

TABLE 7:

PerCePtions OF THE TEACHING OF BUSINESS ETHICS

\begin{tabular}{lcccc}
\hline Value & $\begin{array}{c}\text { SA sample } \\
(\%)\end{array}$ & $\begin{array}{c}\text { Cypriot } \\
\text { sample (\%) }\end{array}$ & $\begin{array}{c}\text { Chi- } \\
\text { Square }\end{array}$ & $\boldsymbol{P}$ \\
\hline $\begin{array}{l}\text { Teaching business ethics to } \\
\text { students can make them better } \\
\text { leaders }\end{array}$ & 89.6 & 82.5 & 1.095 & .295 \\
\hline $\begin{array}{l}\text { Teaching business ethics to } \\
\text { students can prevent some of the } \\
\begin{array}{l}\text { corporate scandals that we have } \\
\text { seen in recent years }\end{array}\end{array}$ & 80.6 & 85.0 & .332 & .564 \\
\hline
\end{tabular}




\section{Discussion}

Proposition No. 1 posited that business students in South Africa and Cyprus differ in their perceptions of ethical work-related practices. The findings of the present study tend to support this proposition. From Table 6, it can be seen that on nine of the 15 statements, Cypriot respondents, significantly more than South African respondents, indicated that they would be willing to engage in unethical workplace practices such as using insider information for gain, harming others to achieve advancement, lying about excess stock and cutting corners on quality. This can be noted within the context of significantly more Cypriot respondents than South African respondents reporting that their workplace ethics differ to the ethics that they practice at home and that competition for business promotes their unethical behaviour (see Table 6). On some of the items, where statistically significant differences between the two samples were indicated, scores are nevertheless low in respect of attitude towards unethical workplace practices. However, of concern is the fairly large percentage of Cypriot respondents reporting willingness to engage in certain unethical work practices (up to 47,5 percent on one item) (Table 6) and the congruence reported between their work and home ethical practices $(65,9$ percent) (Table 6).

It appears that respondent perceptions of ethics in the workplace are congruent with their views of organisational values and practices as noted in Table 5, where perceptions between Cypriot and South African respondents differed significantly on three items, with Cypriot respondents, more so than South African respondents, perceiving that their companies encourage them to compromise their ethical standards and their being involved in using bribes to obtain business. Thus it appears that Cypriot respondents, significantly more than South African respondents, admit to engaging in certain unethical workplace practices and that this occurs against a backdrop of their perceptions of certain unethical practices perpetuated by their companies. This is not to say that South African respondents reported no engagement in unethical work practices and did not perceive their workplaces to evidence unethical practices. However, scores here tended, in the main, to below on the unethical practice dimension.

While generally both South African and Cypriot respondents indicated that they understood what constitutes unethical behaviour and regarded ethics as being important, on almost half of the statements, the Cypriot respondents indicated that they would personally transgress ethical boundaries, for example by falsifying tax returns and by paying bills late (Table 4). In keeping with this finding, significantly more South African than Cypriot respondents expressed congruence between home and work place ethics. With regard to sample members being business students, it is interesting to note that, while no statistically significant differences between samples were found, only 77,6 percent and 61,5 percent of the South African and Cypriot samples respectively, indicated a willingness to sacrifice money to act ethically, somewhat supporting the research of Schwartz, Kassem and Ludwig (1991) and Cowton and Cummins (2003) who note that business students often believe that winning is everything.

As noted in Table 1, the Cypriot sample was younger than the South African sample and, it is proposed, that the differences in ethical orientation could be linked to age. Allmon, Page and Roberts (2000) note how older students evidence more ethical attitudes with regard to classroom behaviour. Dawson (1997), Luther and Karri (2005), and Petersen, Rhoades and Vaught (2001) report that as people become older and grow in work experience, their ethical sensitivity increases. Conroy and Emmerson (2005) indicate that older people have higher ethical values than do younger ones and Deshpande (1997) comments that older managers are more concerned about certain kinds of unethical behaviours than are younger managers. Cabral-Cardosa (2004) emphasises that growth in moral development, while linked to age, is not necessarily linked to education, supporting the differences in certain ethical attitudes to workplace practices between the Cypriot and South African respondents, the former who were more educated at a post-graduate level.

Proposition No. 2 posited that business students in South Africa and Cyprus differ on Hofstede's (1994) dimensions of national culture. This proposition appears not to be supported. From Tables 2 and 3 it can be seen that in only one of the five dimensions i.e. long term orientation, is there a significant difference between the Cypriot and South African samples.

The findings of the present study also contradict those of Hofstede (1994) with regard to the South African sample in that a similarity was found only on the power distance dimension. Scores in the present study were higher on the uncertainty avoidance and individualism dimensions and lower on the masculinity dimension than those reported by Hofstede (1994). Hofstede (1994) did not report results for the LTO dimension. Compared to the study by Thomas and Bendixen (2000), scores reported in the present study evidence similarity on the individualism, masculinity and long-term orientation dimensions.

Proposition No. 3 stated that attitudes to ethical workrelated practices are linked to differences in national culture. This proposition is not supported as no significant differences between the two samples were found in terms of national culture.

Proposition No. 4 stated that business students in South Africa and Cyprus differ in the importance they place on the teaching of business ethics to students. While no statistically significant differences were found between the Cypriot and South African samples, from Table 7 it can be seen that both groups strongly agreed 
that teaching business ethics to students can assist them in becoming better leaders and thereby avert some of the scandals that have become part of corporate life. Other researchers have reported similar findings (Adkins \& Radkte, 2004; Byerly, Dave \& Medlin, 2002; Crane, 2004; Power \& Lundsten, 2001). In further support of the findings of the present study, Premeaux (2005) notes that, in spite of believing that studying ethics is important, students still violate ethical principles.

The findings of the present study serve only to indicate that certain differences in attitudes towards workplace ethics exist between Cypriot and South African students. The findings, in no way, provide a comprehensive picture. Trevino (1986) frames ethical behaviour as a complex system of interactions among different components involving personal and situational factors. Williams and Dewett (2005) note that ethical behaviour also resides within a system where circumstances promote or hinder ethical decision-making. Appelbaum (2005, p. 680) supports this view by stating that "... unethical behaviour is evenly related to the inherent characteristics of the individual and the environmental factors by which he or she is surrounded". This study did not explore any such multidimensional variables among sample members.

While significant differences between the two samples were found on certain questionnaire items, students in both samples indicated that they would be prepared to engage in unethical practices in some instances. As noted by Granitz and Loewy (2007), unethical students can later become unethical managers. The question, therefore, needs to be asked if those tasked with teaching and graduating future business leaders can do anything to influence this occurrence.

Piper, Gentile and Parks (1993) propose that the ethical views of students can be shaped during the course of their studies. In support, Crane (2004, p. 151) notes that "business faculty members may not be able to change the character of scoundrels or influence corrupt individuals, but they can work diligently to persuade the overwhelming majority of students to accept the idea that ethical behaviour should be the overriding imperative in today's marketplace". In this regard, Williams and Dewett (2005) advocate a business ethics education to equip students to later act with moral courage when confronted with business pressures.

It is proposed that, at business schools and institutions offering business degrees, the component of ethics is integrated into the curriculum. Business education provides the ideal vehicle to progress such study with daily live examples of complex corporate and public organisation transgressions that can be used to promote moral reasoning and intensify "moral imagination" (Piper et al., 1993, p. 77). While issues of right and wrong cannot be taught as such, students can be assisted in recognising ethical issues, developing analytical skills, confronting ambiguity, and integrating business competence with the courage to face moral complexity.

\section{Limitations of the study}

Inherent in this exploratory study are the following limitations:

1. The numbers were small in both samples and accordingly, caution must be exercised when generalising the findings to business students in either country.

2. Where respondents were required to rate their agreement or disagreement with various statements, the issue of "social desirability" may have influenced responses and again this could impact on generalising the findings to wider groups.

3. The response categories of "always" and "often" were collapsed as were the categories of "sometimes" and "never", and thus nuances in responses may have been disguised.

4. A study such as the present one simply reports attitudes towards issues; no reasons underlying these attitudes or perceptions were explored which would have provided a richer understanding of the overtly reported responses.

5. In South Africa there are 11 official language groups reflective of people from an array of ethnic backgrounds. Due to the small sample size, no analysis was undertaken to ascertain whether different groups evidence differences on the Hofstede (1994) dimensions, as was attempted by Thomas and Bendixen (2000) in their study of ethnicity in South African management. Accordingly, the clustering of different ethnic groups in the overall South African sample and the resulting national culture profile that emerged could possibly not reflect a true national culture of the country, and

6. Criticism has been levelled against the Hofstede's (1994) VSM instrument (McSweeney, 2002). Kruger and Roodt (2003) found the instrument to evidence poor reliability when tested on a South African sample. If this is the case, the profile of national culture may not be accurate impacting on the comparison of national cultures between South Africa and Cyprus.

\section{Conclusion}

This exploratory study investigated differences in attitudes of management students in Cyprus and South Africa towards workplace ethics. It also investigated differences in national culture between the two groups and whether such differences in attitudes to workplace ethics could be linked to differences in national culture. Conclusions of the study are summarised below:

1. As no significant differences between the two samples exist on four of the five dimensions of national culture (Hofstede, 1994), differences in attitudes towards workplace ethical practices cannot be said to be linked to this variable. 
2. As significant differences were found between the two samples on certain questionnaire items that related to workplace practices, it can be said that the Cypriot sample appeared to be more willing to engage in certain workplace practices that would be deemed unethical in society than would the South African sample. An explanation here could be that the members of the Cypriot sample were younger than members of the South African sample, and that age could be a contributing factor.

3. While statistical differences between samples for certain items were found, for both samples, the scores do not generally reflect a strong agreement with the unethical workplace practices in question and overall, respondents in both groups appeared to favour ethical workplace practices.

4. Linked to the above, significantly more Cypriot than South African respondents noted an incongruence between work and home ethics and the role that business competition plays in promoting the altering of personal ethics. This finding indicates that the situational aspects of the workplace cannot be disregarded when considering employee workplace ethics.

5. In a similar vein, while both groups strongly agreed that their organisational moral standards are understood and that they were satisfied with organisational ethics, Cypriot respondents, significantly more than the South African ones, reported that their companies engaged in unethical behaviour and that their ethical standards are compromised by their companies. The greater tendency for the Cypriot sample to report supporting certain unethical practices could be linked to the environment and culture of the companies that employ them. The fact that respondents from both samples, the majority of whom were employed, reported to some degree being willing to engage in unethical workplace practices (whether these differences were significantly different to each other or not), indicates a possibility that these respondents practice such behaviour in their places of work.

6. While both groups strongly agreed with the teaching of business ethics to develop better leaders and to avert corporate scandals, nonetheless, on the various items (some reflecting statistical differences between the two groups), some students are still prepared to support unethical workplace practices. This finding possibly demands that educators should consider the methodology of teaching business ethics away from a right versus wrong approach to one that actively promotes student engagement and emotional involvement with the issues (McWillians \& Nahavndi, 2006).

It is suggested that future research could focus on the areas noted below:

1. Given the criticisms levelled at Hofstede (1994), an alternative instrument to measure national culture should be considered, such as the one advanced in the GLOBE study (House et al., 2004) that includes additional dimensions to that of the Hofstede (1994) VSM instrument. In this way, coupled to the use of larger samples in both countries, additional information on national culture could be obtained to effect a more meaningful comparison between the two countries than that provided in the present study.

2. A study of national culture in South Africa needs to take cognisance of the diverse ethnic groups that comprise the population and perhaps a more nuanced measure of national culture needs to be identified taking ethnicity into account.

3. An in-depth study involving a number of personal and situational variables and their interactions, could provide a richer understanding of student attitudes towards workplace ethics.

4. The importance of graduating ethical business students who go on to become organisational leaders requires that research attention be focused on identifying best ways in which moral development can be nurtured in the course of an MCom or MBA programme.

Business students go on to become ethical or unethical leaders and managers. As evidence appears to suggest that moral development can be nurtured in a university environment (Crane, 2004), it is strongly suggested that educators of business students explore the best pedagogic methodologies to nurture the development of moral reasoning and ethical exercising in business students. In this way it is hoped that students will develop tools and skills, not only to assist in decisionmaking in mainstream areas of business, but will also develop tools and skills and moral courage to ensure that ethical practices underlie all their business applications.

\section{Acknowledgements}

The authors express their gratitude to professor Deon de Bruin of the Department of Industrial Psychology and People Management (University of Johannesburg) for his helpful comments on the statistical analysis and to Ms Delia Woker for her assistance in the literature search.

\section{References}

Abratt, R., Nel, D. \& Higgs, N.S. (1992). 'An examination of the ethical beliefs of managers using selected scenarios in a cross-cultural environment'. Journal of Business Ethics, 11, 29-35.

Adkins, N. \& Radtke, R.R. (2004). 'Student and faculty members' perception of the importance of business ethics and accounting ethics education: Is there an expectation gap?' Journal of Business Ethics, 51(3), 279-300.

Ahmed, M.M., Chung, K.Y. \& Eichenseher, J.W. (2003). Business students' perception of ethics and moral 
judgment: A cross-cultural study. Journal of Business Ethics, 43(1/2), 89-102.

Alderson, S. \& Kakabadse, A. (1994). 'Business ethics and Irish management: A cross-cultural study'. European Management Journal, 42(12), 432-441.

Allmon, D.E., Page, D. \& Roberts, R. (2000). 'Determinants of perceptions of cheating: Ethical orientation, personality, and demographics'. Journal of Business Ethics, 23(4), 411422.

Amalric, F. \& Hauser, J. (2005). 'Economic drivers of corporate responsibility activites'. The Journal of Corporate Citizenship, Winter (20), 27-38.

Appelbaum, S.H. (2005). "The creation of an unethical work environment: Organisational outcome-based control systems'. Equal Opportunities International, 24(2), 67-83.

Aqueveque, C. (2005). 'Marketing and market development: Signalling corporate values - consumers' suspicious minds'. Corporate Governance, 5(3), 467-479.

Armstrong, R.W. (1996). 'The relationship between culture and perception of ethical problems in international marketing'. Journal of Business Ethics, 15, 1199-1208.

Armstrong, R.W. \& Sweeney, J. (1994). 'Industry, type, mode of entry and perceptions of international marketing ethics problems: A cross-culture comparison'. Journal of Business Ethics, 13(10), 775-785.

Axinn, C., Blair, M.E., Heorhiadi, A. \& Thach, S.V. (2005). 'Comparing ethical ideologies across cultures'. Journal of Business Ethics, 54 (2), 103-120.

Bernardi, R.A., Giuliano, J.L., Komatsu, E., Potter, B.M. \& Yamamoto, S. (2004). 'Contrasting the cheating behaviors of college students from the United States and Japan'. Global Virtue Ethics Review, 5(4), 5-31.

Bok, D. (1990). Universities and the future of America. Durham NC: Duke University Press.

Born, A.D. (2003). 'How to reduce plagiarism'. Journal of Information Systems Education, 14(3), 223-224.

Brimble, M. \& Stevenson-Clarke, P. (2005). 'Perceptions of the prevalence and seriousness of academic dishonesty in Australian universities'. Australian Educational Researcher, 32(3), 19-44.

Byerly, R.T., Dave, D. \& Medlin, B.B.D. (2002). 'Ethics in business program curricula: An empirical investigation of the attitudes and perceptions of United States students'. International Journal of Management, 19(2), 357-365.

Cabral-Cardosa, C. (2004). 'Ethical misconduct in the business school: A case of plagiarism that turned bitter'. Journal of Business Ethics, 49, 75-89.

Casado, M., Miller, W. \& Vallen, G. (1994). 'Ethical challenges of the industry: Are graduates prepared?' FIU Hospitality Review, 12(1), 1-7.

Christies, P.M.J., Kwon, I.G., Stoeberl, P.A. \& Bauhart, R. (2003). 'A cross-cultural comparison of ethical attitudes of business managers: India, Korea and the United States'. Journal of Business Ethics, 46(3), 263-288.

Collins, D. (2000). 'The quest to improve the human condition: The first 1500 articles published in the Journal of Business Ethics'. Journal of Business Ethics, 26(1), 1-73.

Conroy, S. \& Emerson, T. (2004). 'Business education and religion: Religiosity as a predictor of ethical awareness among students'. Journal of Business Ethics, 50, 383-396.
Cowton, C.J. \& Cummins, J. (2003). 'Teaching business ethics in UK higher education: Progress and prospects'. Teaching Business Ethics, 7, 37-54.

Crane, F.G. (2004). 'The teaching of business ethics: An imperative at business schools'. Journal of Education for Business, 79(3), 149-151.

Curren M.T. \& Harich, K.R. (1996). 'Business ethics: A comparison of business and humanities students and faculty'. Journal of Education for Business, 72 (1), 9-11.

Dawson, L.M. (1997). 'Ethical differences between men and women in the sales profession'. Journal of Business Ethics, $16,1143-1152$.

Deshpande, S.P. (1997). 'Managers' perceptions of proper ethical conduct: The effect of sex, age, and level of education'. Journal of Business Ethics, 16(1), 79-85.

Droussiotis, A. (2003). 'Who are we on the way to the EU? The profile of typical Cypriot employees as seen by their managers'. Journal of European Industrial Training, 27(8), 423-434.

Everett, J., Neu, D. \& Rahaman, A.S. (2006). 'The global fight against corruption: A Foucaultian virtues-ethics framing'. Journal of Business Ethics, 65, 1-12.

Fassin, Y. (2005). 'The reasons behind non-ethical behaviour in business and entrepreneurship'. Journal of Business Ethics, 60, 265-279.

Felton, E.L. \& Sims, R.R. (2005). 'Teaching business ethics: Targeted outputs, Journal of Business Ethics'. 60(4), 377391.

Getz, K.A. \& Volkema, R.J. (2001). 'Culture, perceived corruption, and economics'. Business and Society, 40(1), 7-30.

Giacalone, R.A. (2004). 'A transcendent business education for the 21st century'. Academy of Management, Learning and Education, 3(4), 415-420.

Gildia, R.L. (1995). 'Consumer survey confirms corporate social responsibility affects buying decisions'. Public Relations Quarterly, 39, 12-21.

Granitz, N. \& Loewy, D. (2007). 'Applying ethical theories: Interpreting and responding to student plagiarism'. Journal of Business Ethics, 72, 293-306.

Grünbaum, L. (1997). 'Attitudes of future managers towards business ethics: A comparison of Finnish and American business students'. Journal of Business Ethics, 16(4), 451463.

Haswell, S., Judd, P. \& Wearing, B. (1999). 'Accounting students and cheating: A comparative study for Australia, South Africa and the UK'. Teaching Business Ethics, 3(3), 211-239.

Hofstede, G. (1991). Cultures and organizations: Software of the mind. New York: McGraw-Hill.

Hofstede, G (1994). Values survey module (VSM 94). Maastricht: IRIC.

Hofstede, G. (1997). Cultures and organizations: Software of the mind (2nd ed.). New York: McGraw-Hill.

Hofstede, G. (2001). Culture's consequences: Comparing values, behaviors, institutions, and organizations across nations. New York: Sage.

Hofstede, G. \& Bond, M.H. (1988). 'The Confusius connection: From cultural roots to economic growth'. Organizational Dynamics, 16, 5-21.

Holland, T. (2002). 'Ethics pay in the long run'. Far Eastern Economic Review, 165(15), 49-59. 
Hosmir, L. (1994). 'Strategic planning as if ethics mattered'. Strategic Management Journal, 15, 17-34.

House, R.J., Hanges, P.J., Javidan, M., Dorfman, P.W. \& Gupta, V. (2004). Leadership, culture, and organizations: The GLOBE study of 62 societies. Thousand Oaks, CA: Sage.

Husted, B.W. (1999). 'Wealth, culture, and corruption'. Journal of International Business Studies, 30(2), 339-359.

Jackson, T. \& Artola, M.C. (1997). 'Ethical beliefs and management behaviour: A cross-cultural comparison'. Journal of Business Ethics, 16(11), 1163-1173.

Johnstone, P. \& Brown, G. (2004). ' International controls of corruption: Recent responses from the USA and UK.. Journal of Financial Crime, 11(3), 217-249.

Kennedy, E.J. \& Lawton, L. (1996). 'The effects of social and moral integration on ethical standards: A comparison of American and Ukrainian business students'. Journal of Business Ethics, 15(8), 901-911.

Kruger, T. \& Roodt, G. (2003). 'Hofstede's VSM-94 revisited: Is it reliable and valid?' South African Journal of Industrial Psychology, 29(1), 75-82.

Luthar, H.K. \& Karri, R. (2005). 'Exposure to ethics education and the perception of linkage between organizational ethical behaviour and business outcomes'. Journal of Business Ethics, 61, 353-368.

Marsden, H., Carroll, M. \& Neill, J. (2005). 'Who cheats at university? A self-report study of dishonest academic behaviours in a sample of Australian university students'. Australian Journal of Psychology, 57(1), 1-10.

Maynard, M.L. (2001). 'Policing transnational commerce: Global awareness in the margins of morality'. Journal of Business Ethics, 30, 17-27.

McDonald, G.M. \& Kan, P.C. (1997). 'Ethical perceptions of expatriate and local managers in Hong Kong'. Journal of Business Ethics, 16(15), 1605-1623.

McSweeney, B. (2002). 'Hofstede's model of national culture differences and their consequences: A triumph of faith - a failure of analysis'. Human Relations, 55(1), 89-118.

McWillaims, V. \& Nahavndi, A. (2006). 'Using live cases to teach ethics'. Journal of Business Ethics, 67, 421-433.

Merrit, J. (2002). 'For MBAs, soul-searching 101'. Business Week, September 16, 64-65.

Moore, R.S. \& Radloff, S.E. (1996). 'Attitudes towards business ethics held by South African students'. Journal of Business Ethics, 15, 863-869.

Nyaw, M.K. \& Ng, I. (1994). 'A comparative analysis of ethical beliefs: A four country study'. Journal of Business Ethics, 13, 534-555.

Okazaki, S. (2007). 'Cross-cultural advertising research: Where we have been and where we need to go'. International Marketing Review, 25(5), 499-518.

Pacini, C., Swingen, J.A. \& Rogers, H. (2002). 'The role of the OECD and the EU Conventions in combating bribery of foreign public officials'. Journal of Business Ethics, 37(4), 340-385.

Patel, C., Harrison, G.L. \& McKinnon, J.L. (2002). 'Cultural influence on judgments of professional accountants in auditor-client conflict resolution'. Journal of International Financial Management and Accounting, 13, 1-31.

Peterson, D.K., Rhodes, A. \& Vaught, B.C. (2001). 'Belief in universal ethics: Gender differences, influence of referent others, and ethical beliefs of business professionals'. Business and Professional Ethics Journal, 20, 47-55.
Pillsbury, C. (2004). 'Reflections of academic misconduct: An investigating officer's experiences and ethics supplements'. Journal of American Academy of Business, 5 (1/2), 446-454.

Piper, T.R., Gentile, M.C. \& Parks, S.D. (1993) Can ethics be taught? Perspectives, challenges and approaches at Harvard Business School. Cambridge MA: Harvard Business Press.

Power, S.J. \& Lundsten, L.L. (2001). 'MBA student opinion about the teaching of business ethics: Preference for inclusion and perceived benefit'. Teaching Business Ethics, 5(1), 59-70.

Premeaux, S.R. (2005). 'Undergraduate student perceptions regarding cheating: Tier 1 versus Tier 2 AACSB accredited business schools'. Journal of Business Ethics, 62(4), 407418.

Pulley J.L. (2005). 'More schools are teaching social and environmental ethics'. The Chronicle of Higher Education, 52(10), A.34.

Rokeach, M. (1973). Beliefs, attitudes and values. San Francisco: Jossey-Bass.

Ryan, L. (2000). 'Combating corruption: The $21^{\text {st }}$-century ethical challenge'. Business Ethics Quarterly, 10(1), 331338.

Salter, S.B., Guffey, D.M. \& McMillan, J.J. (2001). 'Truth, consequences and culture: A comparative examination of cheating and attitudes about cheating among US and UK students'. Journal of Business Ethics, 31(1), 37-50.

Schwartz, R.H., Kassem, S. \& Ludwig, D. (1991). 'The role of business schools in managing the incongruence between doing what is right and doing what it takes to get ahead'. Journal of Business Ethics, 10(6), 465-469.

Sheard, J., Markham, S. \& Dick, M. (2003). 'Investigating the difference in cheating behaviours of IT undergraduate and graduate students: The maturity and motivation factors'. Higher Education Research and Development, 22(1), 91-108.

Sims, R.L. (2006). 'Comparing ethical attitudes across cultures'. Cross Cultural Management, 13(2), 101-113.

Sims, R.L. \& Gegez, A.E. (2004). 'Attitudes towards business ethics: A five nation comparative study'. Journal of Business Ethics, 50(3), 253-261.

Singhapakdi, A., Rallapalli, K.C., Rao, C.P. \& Vitell, S.J. (1995). 'Personal and professional values underlying ethical decisions: A comparison of American and Thai marketers'. International Marketing Review, 12(4), 65-76.

Sondergaard, M. (1994). 'Research note: Hofstede's consequences: A study of reviews, citations and replications'. Organizational Studies, 15(3), 447-557.

Stahli, A. (2005). 'The stakeholders' perspective on the international business school'. Corporate Governance, 5(2), 121-129.

Sterngold, A. (2004). 'Confronting plagiarism'. Change, 36, 16-21.

Sullivan, R. (2005). 'Just power? Teaching business ethics in a time of maximizing returns'. Connection, New England's Journal of Higher Education, 20(1), 29-30.

Thomas, A. \& Bendixen, M. (2000). 'The management implications of ethnicity in South Africa'. Journal of International Business Studies, 31(3), 507-519.

Transparency International (2007). Corruption Perception Index, www.http://cpi/surveys_indices/policy_research, [accessed 9 April, 2008]. 
Trevino, L.K. (1986). 'Ethical decision making in organizations: A person-situation interactionist model'. Academy of Management Review, 11(3), 601-617.

Tsui, J. (1996). 'Auditors' ethical reasoning: Some audit conflict and cross-cultural evidence'. International Journal of Accounting, 31,121-133.

Tsui, J. \& Windsor, C. (2001). 'Some cross-cultural evidence of ethical reasoning'. Journal of Business Ethics, 31, 143150.

Verschoor, C.C. (1998). 'Corporations' financial performance and its commitment to ethics'. Journal of Business Ethics, 17, 1509-1516.

Walker, R. \& Jeurissen, R. (2003). E-based solutions to support intercultural business ethics instruction: An exploratory approach in course design and development. Journal of Business Ethics, 48(1), 113-124.

Weber, J. \& Getz, K. (2004). 'Buy bribes or bye-bye bribes: The future status of bribery in international commerce'. Business Ethics Quarterly, 14(4), 695-711.

Whipple, T.W. \& Swords, D.F. (1992). 'Business ethics judgments: A cross-cultural comparison'. Journal of Business Ethics, 11, 671-678.

Williams, S.D. \& Dewett, T. (2005). 'Yes, you can teach business ethics: A review and research agenda'. Journal of Leadership and Organizational Studies, 12 (2), 109-120.
Yeung, S.Y.C., Wong, S.C. \& Chan, B.M. (2002). 'Ethical beliefs of hospitality and tourism students towards their school life'. International Journal of Contemporary Hospitality Management, 14(4), 183-192.

Zhang, Y., Straub, C. \& Kusyk, S. (2007). 'Making a life or making a living? Cross-cultural comparisons of business students' work and life values in Canada and France'. Cross Cultural Management, 14(3), 174-195.

Zopiatis, A. \& Krambia-Kapardis, M. (2008). 'Ethical behaviour of tertiary education students in Cyprus'. Journal of Business Ethics, 8(3), 647-663.

Address correspondence to: Prof Adèle Thomas Department of Business Management University of Johannesburg PO Box 524 Auckland Park, 2006 Johannesburg, South Africa e-mail: adelet@uj.ac.za 
Reproduced with permission of the copyright owner. Further reproduction prohibited without permission. 